\title{
RESPONDING TO STUDENT WRITING - POWER AND ROLE RELATIONS
}

\section{Brenda Spencer}

The focus of this article falls on the political and power relations that appear to be inherent in response to student writing. The students involved in this research are first-year Practical English students at Unisa, the vast majority of whom are studying English as an additional language. The researcher is aware of the vast discrepancy between South African students studying in the distance-teaching context and the American classroom context in which much of the research in the field has been conducted to date. Consequently the teacher's response to student writing is restricted in this article to written feedback given by distance-teaching lecturers to student writing submitted for assignments.

Hierdie artikel fokus op die politieke en magsverhoudings wat inherent blyk te wees in die reaksie van onderwysers/dosente op studente se skryfwerk. Die studente betrokke by hierdie navorsing is eerstejaar Praktiese Engelse studente van UNISA. Die meerderheid van hulle neem Engels as addisionele taal. Die navorser is bewus van die enorme verskille wat bestaan tussen die konteks van Suid-Afrikaanse studente wat afstandsonderrig ontvang en die konteks van die Amerikaanse klaskamer (waarop die meeste veldnavorsing tot dusver gerig is). Gevolglik word die bespreking van onderwysers se reaksie op studente se skryfwerk in hierdie artikel beperk tot geskrewe terugvoer gelewer deur afstandsonderrig-dosente op studente se skryfwerk wat as werkstukke ingelewer is.

The issue of 'ownership' of student writing and the need to avoid 'appropriation' of students' work, has received much critical attention (Bolker 1978, Sommers (1982a, 1982b), Burkland \& Grimm (1986), Gay (1983), Reid (1994), Sommers (1992) and Straub (1996). The two most influential articles are Sommers' Responding to Student Writing (Sommers 1982a) and Brannon and Knoblauch's On Students' Rights to their Own Texts. It must be aknowledged right from the outset how difficult it is to achieve an authentic voice in one's writing. A prerequisite is ownership of one's writing, which is inextricably linked to the notion of authority. According to Sommers (1982a) even experienced teachers of writing bow to the authority of theorists and are 'stuck in a way of seeing: reproducing the thoughts of others, using them as guides, letting post-structuralist vocabulary give authority' to their texts. Most writers reproduce 'acceptable truth' and 'imitate the gestures and ritual of the academy' simply because they do not have faith in their own ideas, thus surrendering their authority. It takes great confidence to get to the point where one can 'confront these authorial voices' and enter the dialogue on one's own authority. Somewhere between submission to the experts and a declaration of autonomy a person gains an authentic voice. If this task is so difficult for experienced writers, how much more it must be for a student communicating to an authority figure in a high-risk situation, in a language which, more often than not in the South African context, is not his or her 'mother' tongue. 
The issue of ownership is of paramount importance when texts are read, and it is in this context that student writing is at a distinct disadvantage. Lecturers approach these texts very differently from the way they would read text as readers. It can be argued therefore that student writing does not receive the respect normally accorded to written text. Brannon and Knoblauch (1982:157) cite I.A. Richards' belief that people normally begin reading a text 'with an implicit faith in its coherence, [and] an assumption that its author intended to convey some meaning and made the choices most likely to convey the meaning effectively'. Brannon and Knoblauch (1982:157) go on to say that the tolerance the reader exhibits when approaching the text is based on the 'tacit acceptance of the writer's "authority" to make the statements we are reading', whether they are textbooks, newspaper articles, or literary works. In fact, the claim to superiority can be so powerful that readers will tolerate writing from an author even if it appears to be 'unusually difficult, even obscure or downright confusing'. An example would be the response of readers to Hopkins' poetry. On first reading lines such as

I caught this morning morning's minion, kingdom of daylight's dauphin, dapple-dawn-drawn Falcon ...

readers are likely to attribute the confusion they feel to personal inadequacy. Yet, if these same readers had been reading a student's work they would probably have deemed the writing obscure and in need of clarification and would have littered the margin with abbreviations such as 'awk' and 'voc'! There is a further problem in that many of the readers who respond to student writing are graduates from English Departments where the primary focus is English Literature and the training given is in close analysis of finished products, primarily works selected as samples of the English Literary Canon.

Brannon and Knoblauch (1982:157) explain the shift which occurs when teachers approach a student text :

When we consider how writing is taught, however, this normal and dynamic connection between a writer's authority and the quality of a reader's attention is altered because of the peculiar relationship between teacher and student. The teacher-reader assumes, often correctly, that student writers have not yet earned the authority that ordinarily compels readers to listen seriously to what writers have to say. Indeed, teachers view themselves as the authorities, intellectually maturer [sic], rhetorically more experienced, technically more expert than their apprentice writers.

The power shifts even more to the teacher or lecturer who prescribes the form the writing task will take, focuses on error (thus emphasizing the authoritarian, judging role), and consequently has an 'ideal' text in mind and has the power to pronounce judgement on the task. The power exercised is considerable. Judgements, for example, are sometimes made in high-stake situations, such as entry to a course and permission to exit it!

According to theorists such as Brannon and Knoblauch as well as Sommers, the teacher in this reading scenario 'appropriates' the student text. Sommers explains that 'the teacher appropriates the text from the student by confusing the student's purpose in writing the text with her own purpose in commenting. [When revising] students are more likely to make the changes the teacher wants rather than to work through the text and make the changes he or she 
thinks necessary, since the teachers' concerns imposed on the texts create the reasons for the subsequent changes' (1982:149-150). Brannon and Knoblauch claim that the message that our reading of student writing gives is that

the teacher's agenda is more important than their own, that what they wanted to say is less relevant than the teacher's impression of what they should have said. ... they are forced to concede the reader's authority and to make guesses about what they can and cannot say. One consequence is often a diminishing of students' commitment to communicate ideas that they value and even a diminishing of the incentive to write (1982:158-159).

One can hypothesize that this reduction in incentive would work against the possibility of improvement. In short, what Brannon and Knoblauch claim is that teachers lose more than they gain 'by preempting their control and allowing [their] Ideal Texts to dictate choices that properly belong to the writers' (1982:159). The students lose confidence and defer to the voice of the academy. The effect, in Sperling \& Freedman's words, is that 'a good girl writes like a good girl' (1987:343). Alternatively stated, the danger is that students will begin to write 'in the voice of Everystudent to an audience they think of as Everyteacher' (Sommers 1992:29).

The problem of students bowing to the authority of 'Everyteacher' is apparent even from the earliest writing experiences students have. In Anson's words: 'Even young children often see their teachers as dictators, controlling the form and content of students' writing and thus hindering personal exploration and development (1989:345). Yet, the irony is that this appropriation is the result of a desire to assist development. The irony is compounded in that feedback comes at a huge cost to the teacher in terms of the time and effort put into responding to student writing and is the result of the teacher's desire to assist students to become more effective writers.

It can be argued that this is misdirected energy. In a study of the commenting styles of 35 teachers and those of a computer program entitled 'Writer's Workbench' at New York University, Sommers (1989:149) found that within a few minutes the computer program had:

* delivered editorial comments,

* identified all spelling and punctuation errors,

* isolated wordy or misused phrases,

* offered a stylistic analysis of sentence types, beginnings and sentence lengths, and

* provided a readability score.

According to Sommers (1982:149), all of this was conveyed in calm, reasonable language!

Sommers (1989) reveals that teachers frequently gave contradictory messages, for instance, simultaneously instructing students to edit, to avoid errors and to condense and then saying that their paragraphs needed to be developed more:

'the interlinear comments and the marginal comments represent two separate tasks for this student; the interlinear comments encourage the student to see the text as a fixed piece, frozen in time, that just needs some editing. The marginal comments, however, 
suggest that the meaning of the text is not fixed, but rather that the student still needs to develop the meaning by doing some more research. Students are commanded to edit and develop at the same time' (1982:150).

Another significant finding is no indication of the level of importance of various problems is given with the result that a comment on a spelling error seems to carry the same weight as one on organization. The commentary often encourages students to reduce the writing process to one of a 'rewording activity' (Sommers 1982:151). Sommers argues that teachers' commentary often results in a reduction of risk-taking behaviour with students making only the changes requested and not chancing any further alterations, even if they believed these would be beneficial (1981:152). Another problem Sommers identified was that teachers' comments were frequently 'not text-specific and could be interchanged, rubber-stamped, from text to text' (1981:152). The irony lies in the fact that the teacher is non-specific or even vague, even in his or her very injunction to the student to be specific!

The situation is compounded by what Anson terms 'the schizophrenia of roles' (1989:2) that teachers adopt when they respond to student writing. Purves (in Probst 1989:72) has identified the following roles: "common reader", "copy editor/ proof reader", "reviewer or gatekeeper", "critic", "diagnostician/ therapist". If one acknowledges Transactional Theory in which meaning resides 'not on the page, but in the transaction between reader and text' (Probst 1989:69), then one has to accord the teacher the additional role of co-author of the text. In the classroom, the role of facilitator can conflict with that of diagnostician. The former is positive, indicative of guidance and support and suggesting a tentative and cautious attitude in a joint search for meaning. In contrast, the role of diagnosticians implies a critical judge, an authority figure, one who imposes criteria. The possible confusion resulting from multiple roles can, however, be reduced by a declared focus for a specific reading. This is didactically sound as certain of the roles are preferable for specific stages on the teaching/learning time line. For example, the appropriate response to an initial draft would be reading for meaning while, in the final draft, evaluation becomes unavoidable. The proofreading role is vital when students are polishing drafts as preparation for publication. Wherever possible, the teacher should separate roles and it should be clear to the student how a specific text is to be read.

Existing literature is very severe in its criticism of the reader who reduces her response to that of someone with an ideal text in mind. Our biases will determine how we will comprehend the text. Sommers (1982:154) for instance contends that when we 'expect to find errors, ... the result is that we find errors and misread our students' texts'. Then the classroom situation is reduced to that of opponents 'sparring in a linguistic ring, the student attempting to slip confusions and inadequacies past the teacher, and the teacher attempting to catch, label, and castigate all the flaws' (Probst 1989:70). The consequences are spelled out by Probst: 'If schooling leads students to expect only the hostile reader, or only the reader who serves as proofreader, or only the reader who serves as the gatekeeper, then writing will come to seem less a pursuit of meaning than a survival exercise' (Probst 1989:78).

The teacher inevitably serves as gatekeeper, a term defined by Purves as 'one charged with admitting or not admitting, of approving or not approving ... [who] act[s] not as surrogates for the common reader, but as surrogates for various establishments' (in Probst 1989:77). Gatekeeping, however, is all too often associated with exclusion. The role of the teacher must be to provide the skills which will enable the student to be included in the establishment. 
Teachers should view themselves as 'manager[s] of a small interpretive community - the class - and the representative[s] of a larger one - the discipline of language and literary studies. The teacher's role, then, is to initiate students into those communities, to engage them in the dialogue necessary to produce knowledge. ... [to help students] to re-see and re-think within the context of an interpretive community' (Probst 1989:70).

Thus far, the discussion has related primarily to research conducted in the United States classroom context, where the student/teacher ratio is enviable. As it cannot be assumed that findings from research conducted in this context can be generalizable to the post-school, distance-teaching context, a questionnaire ${ }^{1}$ was designed by the author to explore Unisa students' perceptions of the divergent teaching roles and the power relations inherent in writing. 2640 Practical English students responded to the questionnaire. The students' perception of the lecturer's role revealed that $60 \%$ of the students regard the primary role [my emphasis] of the lecturer as that of an 'evaluator', 17\% selected the term 'examiner' and $4 \%$ chose 'judge'. All three terms are indicative of the perception that the lecturer's main role is one of according relative weight to work, of judging merit. The connotative value of the words differs. The students' choice among the three terms reflects a preference for the most positive expression of the judging role ('evaluator') to the role of examiner, to the most negative expression (judge). Though the lecturers' primary goal is perceived by a total of $81 \%$ of the students sampled in a judging role, the majority of those students see this as a benign expression of that role. Only $13 \%$ of the students describe the primary role of the lecturer as that of 'an interested reader'. The significance of this statististic is not clear. It can not be seen as definite evidence that students do not value the tutor as reader. It could simply imply that this is not perceived to be the lecturer's 'primary' role. The fact that a mere $4 \%$ of the students selected the role of 'editor' as the lecturer's primary goal suggests that students do not see the lecturers as primarily focusing on formal correction of errors above all else. It is important to note, that this question did not require students to assign value to the various roles. Thus, a low response does not imply that students perceive a particular role as valueless, simply that this is not perceived as the lecturer's primary role in responding to student writing.

It was reassuring to find that $95 \%$ of the students in this research sample perceive the responsibility for improvement in their writing to be their own in contrast to $4.7 \%$ who regard the lecturer as responsible for enhancing their proficiency. The level of maturity of the response to this question can probably be traced to the fact that the majority of the students at Unisa are responsible, employed adults studying part-time. It is a fair assumption that the result would be different in the school context. However, it is important to remember that the power relationships are not a simple either/or structure, as the question formulation implies, but rather a matter of power sharing.

Power relationships are dependent on the attitude teachers take to student texts. If teachers adopt an evaluative attitude which views the text as closed, 'self-contained, complete in itself.

Discussion of the findings of this questionnaire are due to be published in SAJALS, Volume 6, no. 1 of 1998 in an article entitled Responding to Student Writing: The Students' Perspective. 
... independent of other writings' (Phelps 1989:49-50) then there is a danger that response will be reduced to marking, ranking and identifying errors. Alternatively, a formative attitude towards an evolving text, where one works with drafts and samples of the composing process, encourages a view of composing as a 'sequence of relatively fixed stages [where] ... the text becomes less important for itself than for what it may point to in the way of unrealized intentions - a fact that considerably changes the interpretative task of the reader' (Phelps 1989:51). Here the reader becomes part of the composing process, the need to judge is obviated and the focus falls on 'the deficit between what the text is and what it could be' (Phelps 1989:52). The teacher is then a reader and the possibility of peer readers becomes more feasible if this approach to reading is taken.

There is also the possibility of adopting a developmental attitude towards a portfolio of work. Here the 'text itself blurs as an individual entity ... it is treated simply as a sample excerpted from a stream of writing ... part of the "life text" each literate person continually produces' (Phelps 1989:53). In responding to the portfolio, the reader focuses on the writer's development. The teacher can also adopt a contextual attitude in which the 'implied hermetic seal on a text as sole product and property of a single author' (Phelps 1989:55) is questioned. New, more socially orientated notions of construing text seem to raise a different kind of boundary question, not of circumscription but of semiotic autonomy. How much is a text self-authored? How much of it coauthored?' (Phelps 1989:55). This relates to Bakhtin's term "'heteroglossia" - the incorporation of "another's speech in another language" (Phelps 1989:56).

The teacher's attitude is not necessarily limited to one of these response styles. The portfolio assignment, printed as Addendum 1, is an example of a task set for a Practical English Business Communication assignment in which strong developmental and contextual attitudes are implicit. However, correctness is not overlooked and the students are aware that the document must be as perfect as possible because it will be judged with an evaluative attitude. The task manages to shift responsibility to the students, not only for the choice and ordering of the documents, but also in that they have the power to approve publication of their work. Co-authorship, inevitable in the real business world, is permissible provided it is acknowledged. The student also determines the focus of the response as the teacher reacts in accordance with the aim the student hoped to achieve with the document. In this way a formative attitude is adopted as the focus in responding will fall on the gap between what the text aimed to achieve and what it accomplishes.

Anson demonstrates the importance of Perry's taxonomy of cognitive development along a continuum from dualistic, to relativistic and then to the more mature reflective mode (Perry 1970) to student writing. He explains that during the dualistic phase, students 'often see the world of knowledge in polar terms: right vs. wrong, good vs. bad. Authorities (teachers) possess all the answers ... Learning means collecting these right answers by passively receiving them from Authority. Dualistic students believe that if they adhere to the rules and regulations of Authority, they will succeed' (Anson 1989:334). They tend to be dogmatic, egocentric and value correctness of form and content above all else. Onore makes the link between this cognitive level and the traditional classroom 'with its rigid authority structure and its ready-made forms and meanings ... the traditional classroom ... sustains the illusion that universal definitions of improvement for writers and text can be formulated' (Onore 1989:233). 
A more mature, relativistic view comes with the realization that not all knowledge is absolute. The danger which accompanies this phase is expressed by Anson (1989:336):

'Since no one can be an authority about what constitutes "good" or "bad" writing, "correct" or "incorrect" decisions, then personal idiosyncrasy can prevail, immune to criticism'.

The result is frequently 'an endless weighing of alternatives, a kind of inconclusiveness born of entertaining diversity' (Anson 1989:337). When writers begin to find stability and resolution, evaluate various alternatives, and take logical, well supported stands, then they are defined as 'reflective writers'. Anson (1989:338-339) explains that 'here the writer's commitment to an opinion is based on a process of analysis and balanced thought. ... In essence, the scheme charts the intellectual transition away from the accumulation of "right answers" and toward the reflective world view inculcated by a liberal education, which is an overarching goal of college [university] education.' Whereas dualistic writers tend to surrender their power to an all-knowing authority, relativistic writers go to the other extreme and defy authority. In contrast,the reflective writer takes the more central, balanced position that he or she is entitled to any well-substantiated argument.

Anson (1989) conducted research on the response styles of 16 teachers to the writing of highrisk, mainly minority college students. His finding is that although the teachers response styles differered radically, each teacher had his or her dominant response style that did not vary regardless of any cognitive-level discrepancies in the essays they evaluated. He believes that teachers also conform to the 'different epistemological assumptions categorized in Perry's scheme' (1989:339). The majority of teachers - about three-fourths - could be classed as dualistic in that they used response styles that focused almost entirely on the surface features of the students' texts' (Anson 1989:344). They perceive their role as that of a judge and upholder of standards and regard meaning as secondary to linguistic and rhetorical correctness. This dualistic responder offers little in the way of suggestions for revision. This type of response can have a negative effect on the student: 'The next time around, if he takes the risk, he may well be penalized for making more errors' (Anson 1989:345).

In contrast, the very small group classified as relativistic responders have few marginal comments and seem content with a 'casual reaction, as if this is the only kind of response that can have any validity in a world where judgement is always in the eye of the beholder. In this style, very little is imposed on the student; the text seems "owned" by the writer and the teacher stands outside it' (Anson 1989:349). Paradoxically, this approach appears to have benefits for the less advanced student 'whose lack of fluency may be tied to his fear of error' (Anson 1989:349). The teacher concentrates on meaning, 'a tendency that, given recent theories of response ... would seem preferable to error-hunting' (Anson 1989:350).

The mature reflective responders, unfortunately also a very small group, give tentative rather than dogmatic suggestions for revision. Their preferences are made as 'representative readers - members of the classroom and the wider social community' (Anson 1989:351). Writing is viewed as an in-process draft which serves to promote increased writing proficiency. The text assumes a central position as the means by which the reader responds to the writer's meaning. These three types of response are 'positions along a continuum of 
development, from the rigidly dualistic style to the balanced, mature, reflective style. ... perhaps this continuum of development is related to the depth of a teacher's explorations into the practice and teaching of composition' (Anson 1989:356). A 'solution' can only begin with teachers being able to identify their response style and becoming aware of the implications of various response styles.

At this stage of the paper I would like to make tentative suggestions about possible 'solutions' to assist the teacher in moving away from the authoritarian mode towards one where more power and responsibility are transferred to the student.

The first lies in teacher education. Teachers need to know about the possible frameworks of response so that they realise that they have choices in the way that they respond and that these choices have pedagogical implications. They need to be aware of the student's developmental stage and to be able to adapt their response style accordingly. At the same time there is a need for teachers to guard against the pitfalls inherent in an either/or logic, in viewing all response strategies in a dualistic light. Various strategies belong at different points on the authority / freedom line. The teacher's aim should be to strive towards response styles that allow freedom, those that can be classified as facilitative (Straub 1996), collaborative, and feminine (Flynn 1989). Yet teachers also need to be aware that no single response style can ever be ideal because teaching is too context specific. In reality teachers must strive for a workable option for a particular teaching context. [This represents a rich area of experimentation and research.]

An attitudinal shift is also necessary on the part of the teacher. By consulting the student about what he or she wanted to achieve with the text, the emphasis will fall on the disparity between what the writer wanted to communicate and what the choices residing in the text actually caused the readers to understand. Writers know what they intended to communicate. Readers know what a text has actually said to them. If writers and readers can exchange information about intention and effect, they can negotiate ways to bring actual effect as closely in line with a desired intention as possible (Brannon and Knoblauch 1982:161-162).

Another possible solution lies in Freedman's injunction that teachers move from talking about writing to practising the art themselves (1987:33). The truism that people learn to write from writing extends to teachers. If teachers write themselves, the teacher's role will shift from that of authority to one of practitioner, learner and fellow writer. Mutual inquiry could take place. It would be easier for the student to risk, explore and be fully committed to the writing process, if the teacher is seen to be wrestling with similar issues also. The teacher needs to be an inquirer in this view. 'If the composition classroom is to be a context for exploration and risk-taking, for finding and solving problems - in short, for learning - then power must be shared' (Onore 1989:232), and the teacher who is a writer also should find it easier to create this climate.

Another improvement can be made by teaching writing as a process rather than as a product. By insisting on multiple drafts the teacher invites the student to clarify and refine meaning. The problem with most teacher commentary is that the implication of closure is implicit in the 'corrections'. On early drafts the teacher needs to emphasize the role of reader and inhibit the editorial function to a degree. The roles reverse for the final draft. However, it is important to remember that teacher intervention does not guarantee improvement, but it affords the 
learner an opportunity to practise and, in the process, to reassert control over the text. Sommers (1992:26) believes that despite the teachers' best intentions, 'we have left unexamined the most important fact of all: revision does not always guarantee improvement; successive drafts do not always lead to a clearer vision.' But teachers should not despair as the process of engaging in writing should promote fluency.

The present educational systems' obsession with marks is, I believe, at the heart of the power problem. Marks provide extrinsic motivation and serve as external stamps of approval. There is a need to separate 'response' and 'marks'; 'sharing' and 'evaluation'. Students need to learn that a good mark is not an end in itself but a 'by-product of the care and attention [the writing process] demands' (Freedman 1987:34). Sommers (1982) explains that response is frequently linked to marks and that the emphasis then shifts from thoughtful response to a justification of the mark/symbol awarded. The role of evaluator can easily overshadow and even negate the other reader roles that the teacher needs to adopt to facilitate learning. Freedman explains that students have been conditioned by a school system 'where evaluation with respect to one's peers, not individual learning and accomplishment, is the mark of success. Thus it is little surprise that even in classrooms where teachers focus their attention on the teaching-learning process, students still focus their attention on evaluation. ... The comments and the marks provide the most official and permanent record of the teacher's response; they are the tangible bit that the student "takes away" from the class' (1987:90-91). Marks increases as students become more senior and for many students 'marks' loom larger than what they learn. These students seem to be caught in an institutional bind; marks (the school's and society's measure of learning) and the response that accompanies marks (and often justifies them) are confused with and become more important than the feedback that is more essential to helping them to learn. The students become more interested in the product of learning than in the learning process' (Freedman 1987:158). Freedman explains that 'radical reorganization of classrooms will be needed to make writing and learning more important or even as important as grading from the students' point of view' $(1987: 161)$.

Teachers need to move towards a form of assessment which is not restricted to monitoring, but aims to improve performance. As Wiggins points out, the etymology of the term assessment is indicative of its client-centered nature as 'assess' is a form of the Latin word assidere, meaning to 'sit with', in other words to act with and for the student. Of even greater significance is the observation Wiggins makes that the alternative meaning given in the Oxford English Dictionary is that this person who 'sits beside' the student is one who 'shares another's rank or dignity' and yet is 'skilled to advise on technical points' (1993:14). Assessment is not limited to a single test situation but should be present in the 'model/practice/feedback/refine' (Wiggins 1993:8) cycle. Assessment is a 'comprehensive, multifaceted analysis of performance; it must be judgement-based and personal' (Wiggins 1993:13). Assessment uses a range of techniques to observe performance and integrate the information to form a judgement. Yet the teaching situation seldom reflects this ideal scenario. The bottom line, spelt out by Brannon and Knoblauch (1982:165), remains: 'Eventually, of course, teachers judge student writing, and they invoke standards in the process'. However, this judgement should only come after opportunities for revision in multiple drafts and when the student feels the document is ready for evaluation. As Brannon and Knoblauch (1982:165) explain evaluation remains the natural conclusion of this process of negotiation through successive drafts but that if the spirit is one of consultation rather than 
dictatorial intervention, control can be returned to the place where it belongs, which is with the writer of the text.

Indeed, the unevenness of the power relationship in the traditional teaching context is the very reason why student rights need to be formalized. Wiggins's 'Assessment Bill of Rights' (1993:28) and the 'Writing Assessment: A Position Statement' authored by the CCCC Committee on Assessment (see http://www.missouri.edw/ccc95/assessment. html) are both attempts to address this inequality by formalizing student rights in this context:

Students are entitled to:

* Authentic 'real-world' tasks.

* Clear, apt, polished, and consistently applied teacher criteria in marking work and models that exemplify standards.

* Minimal secrecy about the purpose of the assessment, the way results will be used and their avenues of appeal.

* Have their work evaluated by more than one reader.

* Multiple and varied opportunities to produce samples.

* The freedom to question testing procedures and marking methods which they believe to be flawed.

* Genuine feedback: usable information on strengths and weaknesses and accurate assessment of their progress towards defined exit-level standards.

* Scoring/grading policies that provide incentives and opportunities for improving performance.

South Africa is far removed from the United States as far as teaching context is concerned. In the overcrowded South African classroom and the distance-teaching context the ideal of multiple drafts and readers is difficult to attain. However, in this context, peer readers and email technology can eliminate some of the difficulties of providing readers, particularly for initial drafts. One of the reviewers of this article commented that if the criteria were indeed as clear as is suggested in the document, then a formula for writing would exist and success would relate to the satisfactory observance of those criteria!

The problem/solution format adopted in this article has an implicit danger inherent in its invitation to oversimplify complex interrelationships. I would like to conclude with the warning that 'one has to guard against either/or logic: It is not as simple an issue as either deferring to authority or resisting it. It is not as simple as this as the relationship between authority and language is "delicate"' (Sommers 1992:25). 


\section{ADDENDUM 1: SAMPLE ASSIGNMENT}

\section{PORTFOLIO OF BUSINESS DOCUMENTS}

The steps you will need to follow are outlined below:

Identify four business documents that you have written that you regard as the best examples of your writing. You can choose any type of writing (reports, memo, minutes, letters etc.) but you must not duplicate any documents. You may not, for example, submit two business letters.

Review each document carefully. Is this document as perfect as you can make it? Make any changes you think are necessary. Once you are satisfied that each document is as close to perfect as you are able to make it, you are ready to go to the next step. Arrange your documents in sequence from the document that you regard as your most impressive to the one that you think is the least effective. Label them from Document 1 to Document 4.

Write a brief paragraph as an introduction to each text. In this introduction you should provide the following information:

Identify the type of business document. Use this as a heading (eg Document 1: Business Letter).

Describe the situation that gave rise to the document. Explain what you hoped to achieve in the document.

State if there anything special that the reader needs to know about the format of the document.

Describe any factors in the production of the document that you regard as interesting. (Brainstorming the topic, drafting or editing are important here.)

Define the register (formal, informal) that was used in the document and explain why was this register was chosen.

Acknowledge any assistance you received with the document. Here you will need to outline the extent of editorial, secretarial or other help you received.

List any aspects of the document that you believe could still be improved.

Identify the features of the document that you regard as successful.

Do you give permission for this document to be published either in a tutorial letter or as an exercise for future Practical English students? Simply write yes or no at the end of your paragraph. 


\section{BIBLIOGRAPHY}

ANSON, CM (Ed). 1989. Writing and response: theory, practice, and research. Urbana, Illinois: National Council of Teachers of English.

BOLKER, J. 1978. Reflections on reading student writing. College English, 40: 181-185.

BRANNON, L AND CH KNOBLAUCH. 1982. On students' rRights to their own texts: A model of teacher response. College Composition and Communication. 33: 157166.

BURKLAND, J AND N GRIMM. 1986. Motivating through responding. Journal of Teaching Writing, 5: 237-247.

CCC Committee on Assessment. 1995 (http://www.missouri.edu/-ccc95/assessment. html)

FLYNN, E. 1989. Learning to read student papers from a feminist perspective. In Lawson et al. 1989.

FREEDMAN, SW. 1987. Response to student writing. Urbana, Illinois: National Council of Teachers of English.

GAY, P. 1983. How attitude interferes with the performance of unskilled college freshman writers. Final Report. Old Dominion University Research Foundation: Norfolk.

LAWSON, B, SS RYAN AND R WINTERWOLD (Eds). 1989. Encountering student texts: interpretive issues in reading student texts. Urbana: NCTE.

ONORE, C. 1989. The Student, the teacher, and the text: negotiating meanings through response and revision. In Anson 1989: 231-260.

PERRY, WG. 1970. Forms of intellectual and ethical development in the college years: A scheme. New York: Holt, Reinhart, and Winston.

PROBST, RE. 1989. Transactional theory and response to student writing. In Anson 1989:68-79.

PHELPS, LW. 1989. Images of student writing. In Anson 1989:37-67.

REID, JM. 1994. Responding to ESL students' texts: The myths of appropriation TESOL Quarterly, 28 (2): 273-292.

SOMMERS, N. 1979. The Need for Theory in Composition Research. College Composition and Communication, 30: 46-49.

SOMMERS, N. 1982. Responding to Student Writing. College Composition and Communication, 33: 148-156. 
SOMMERS, N. 1982b. Revision strategies of student writers and experienced adult writers. College Composition and Communication, 33: 378-388.

SOMMERS, N. 1992. Between the drafts. College Composition and Communication, 43 (1): 23-31.

SPERLING, M AND SW FREEDMAN. 1987. A good girl writes like a good girl. Written Communication, 4: 343-369.

STRAUB, R. 1996. The concept of control in teacher response: defining the varieties of 'directive' and 'facilitative' commentary. College Composition and Communication, 47 (2): 223-251.

WIGGINS, G.P. 1993. Assessing student performance: exploring the purpose and limits of testing. San Francisco: Jossey-Bass Educational Series. 